\title{
Journal of Technology and Science Education
}

\section{METHODOLOGY FOR DEVELOPING TEACHING ACTIVITIES AND MATERIALS FOR USE IN FLUID MECHANICS COURSES IN UNDERGRADUATE ENGINEERING PROGRAMS}

\author{
P. Javier Gamez-Montero, Gustavo Raush, Lluis Domènech, Robert Castilla, Mercedes García-Vílchez, Hipòlit \\ Moreno, Albert Carbó \\ Department of Fluid Mechanics, Universitat Politècnica de Catalunya (UPC) \\ Spain \\ pjgm@mf.upc.edu, gustavo.raush@upc.edu, luis.miguel.domenech@upc.edu, castilla@mf.upc.edu, mercedes.garcia-vilchez@upc.edu, \\ hmoreno@mf.upc.edu, albert.carbo@mf.upc.edu
}

Received July 2014

Accepted January 2015

\section{Abstract}

"Mechanics" and "Fluids" are familiar concepts for any newly-registered engineering student. However, when combined into the term "Fluid Mechanics", students are thrust into the great unknown. The present article demonstrates the process of adaptation employed by the Fluid Mechanics course in the undergraduate engineering program, along with the teaching methodology, teaching materials and results obtained, evaluating the final objective in terms of student satisfaction and level of learning.

Keywords - Online questionnaire, Learning strategies, Student-centered methodology, Interdisciplinary, Engineering, Motivation.

\section{INTRODUCTION}

The establishment of the European Higher Education Area (EHEA) has led to important changes in our university education system, and thus in engineering programs. In spite of the fact that articles such as that by Mills and Treagust (2003) show a clear need for change in teaching methodology, away from the dual notion of teachingprofessor and towards that of learning-student, engineering programs continue to show an unfortunate inclination towards the former approach. This is in spite of the fact that this discipline allows for a multitude of learning tools.

The overall environment also plays an important role in the university education system, in which providing students knowledge with a fundamentally theoretical structure fails to develop the practical skills and abilities that are so needed by the job market. Problem solving is an inherent part of the field of engineering.

The teaching-learning process of Fluid Mechanics has been characterized by being difficult and uninteresting for many engineering students. Some very interesting experiences have been introduced to address this, such as project-based learning (Barrio, Blanco, Martinez \& Galdo, 2010). As Gad-el-Hak (1998) describes it, the art of fluids in motion came about in an empirical manner, with no clear idea of what either a fluid or mechanics even were. It originated through experimenting, for example, with the difference between the wind's effect on streamlined and bluff bodies. Nevertheless, at an engineering level, this discipline still remains a great unknown, in spite of its function, rigor and interdisciplinary nature.

Within their teaching methodology, professors must contemplate the potential lack of interest or participation by students in class and the difficulty of understanding concepts or with oral and written expression. It must also be assumed that it is possible that the instructor's teaching strategies do not match the learning styles of 
most of the students, which does not promote a positive climate of motivation and assimilation for the teaching-learning process. Learning is not teaching; we must teach to learn.

Generally speaking, the type of student registered for Fluid Mechanics knows little about the subject, and has a keen interest in the core subjects to the detriment of more interdisciplinary knowledge. There is also the handicap that the subject is studied hand in hand with other basic subjects, or even after them. To summarize, Fluid Mechanics students can be characterized by some of the following characteristics:

- A lack of motivation that comes from not knowing anything about its content

- The obligation to take the course, since it is a common core subject for the degree

- A lack of interest that results from not seeing its application/usefulness in terms of their major or specialty

- A lack of satisfaction resulting from taking the course and not reaching the established expectations

One reference we have is the Kolb model (1984), which classifies student learning styles into four categories, based on how the student processes the information that is received:

- Acting, in the case of active students: he/she learns from a concrete, direct experience, putting the concepts into practice in new situations.

- Reflecting, in the case of reflective students: he/she learns through reflective observation and thinking about the experiences received.

- Theorizing, in the case of theoretical students: he/she learns through abstract conceptualization, obtained by reading or having things explained.

- Experimenting, in the case of pragmatic students: he/she learns by actively experimenting with the information received.

This present work makes no attempt to base itself on the planning and design of strategies based on learning styles and the Kolb model, rather on a teaching methodology that uses teaching tools that lead to the productive learning of Fluid Mechanics, with activities that appeal to all learning styles. At the same time, this methodology must motivate students, highlight important concepts, employ simple examples and refrain from repetition, while leaving aside obsolete methods and procedures that have fallen into disuse. As Felder (2014) rightly explains, in an introductory Fluid Mechanics course, it is not of much use to dedicate three classroom lectures to a detailed derivation of the Navier-Stokes equations when the professor will not put it on a test and it is not within the realm of application of undergraduate engineering students.

Thus, this work focuses on three main objectives:

- The instructors' objective: to implement a teaching method that uses a number of varied and diverse tools that lead to the productive learning of Fluid Mechanics.

- Objective of the work presented: to evaluate, from a qualitative and a quantitative perspective, the effectiveness of the teaching methodology in terms of learning by students of Fluid Mechanics, based on different parameters that come into play.

- Final objective: to improve the instructional quality, which coincides with increased levels of learning, better academic results and greater satisfaction on the part of students studying Fluid Mechanics.

\section{THE ENVIRONMENT AND CONTEXT SURROUNDING THE FLUID MECHANICS COURSE}

"Mechanics" and "Fluids" are familiar concepts for any newly-registered engineering student. However, when combined into the term "Fluid Mechanics", students are thrust into the great unknown; when you start to have an idea about it, you find yourself sitting in class, faced with an exam over it in the near future. One very interesting case is that presented by Gynnild, Myrhaug and Pettersen (2007), in which a laboratory and a computational algebraic program is used in class to introduce the phenomena of Fluid Mechanics. Other recent experiences that have successfully increased student motivation have been based on games and atypical experiments (Absi, Nalpas, Dufour, Huet, Bennacer \& Absi, 2011) and on touch screen devices used for dynamic learning experiences (Kumar, Ramana, Afrin, Ortega, Agarwal \& Udoewa, 2013). Figure 1 shows a diagram summarizing the 5 pillars that constitute the environment and context surrounding Fluid Mechanics.

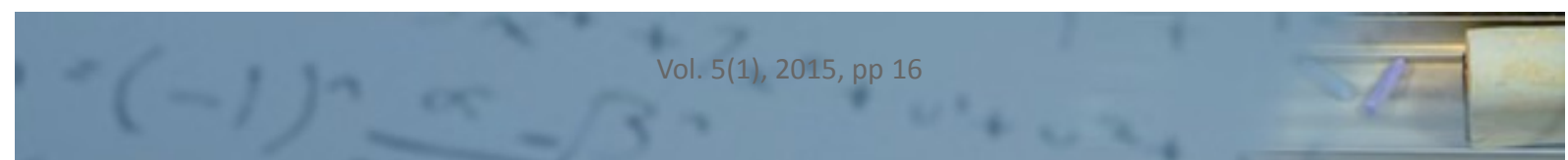




\subsection{The Structure}

The Fluid Mechanics course presented in this paper is a common core subject worth 6 ECTS points in the second year of the undergraduate engineering program for 5 different specialties: Electrical Engineering (EL), Industrial Electronics and Automation (IE), Mechanical Engineering (M), Chemical Engineering (CH) and Textile Technology and Design ( $T$ ), each of which is taught at the Escola d'Enginyeria de Terrassa (EET) of the Universitat Politècnica de Catalunya (UPC). It is a common required course for all undergraduate students, and therefore it must have a broad, general focus (with both the positive and negative aspects that this entails), as the aim is to meet the needs of the different technological profiles of the undergraduate degree programs offered.

The courses have an average of 225 students registered for classes taught by 7 professors, and therefore it must be emphasized that a large number of the students take the course during the same quarter and all of them participate in the same activities. The students are divided into:

- 4 large groups (LG) for theoretical classroom lectures (groups A, B, C and D), with 2 hours of face-toface instruction per week. Each lecture group has a different professor.

- 4 large groups (LG) for problem-solving exercises (groups A, B, C and D), with 1 hour of face-to-face instruction per week. Each exercise group has a different professor.

- 12 small groups (SG) for laboratory work, with 2 hours of face-to-face instruction every two weeks. Several small groups have the same professor for laboratory work.

However, students from the 5 specialties are not evenly divided among groups A, B, C and D, as shown in Figure 2 below. Furthermore, it should also be kept in mind that those students who had not yet selected a major at the time they registered for this course have been categorized as "No specialty" (NS) in this work.

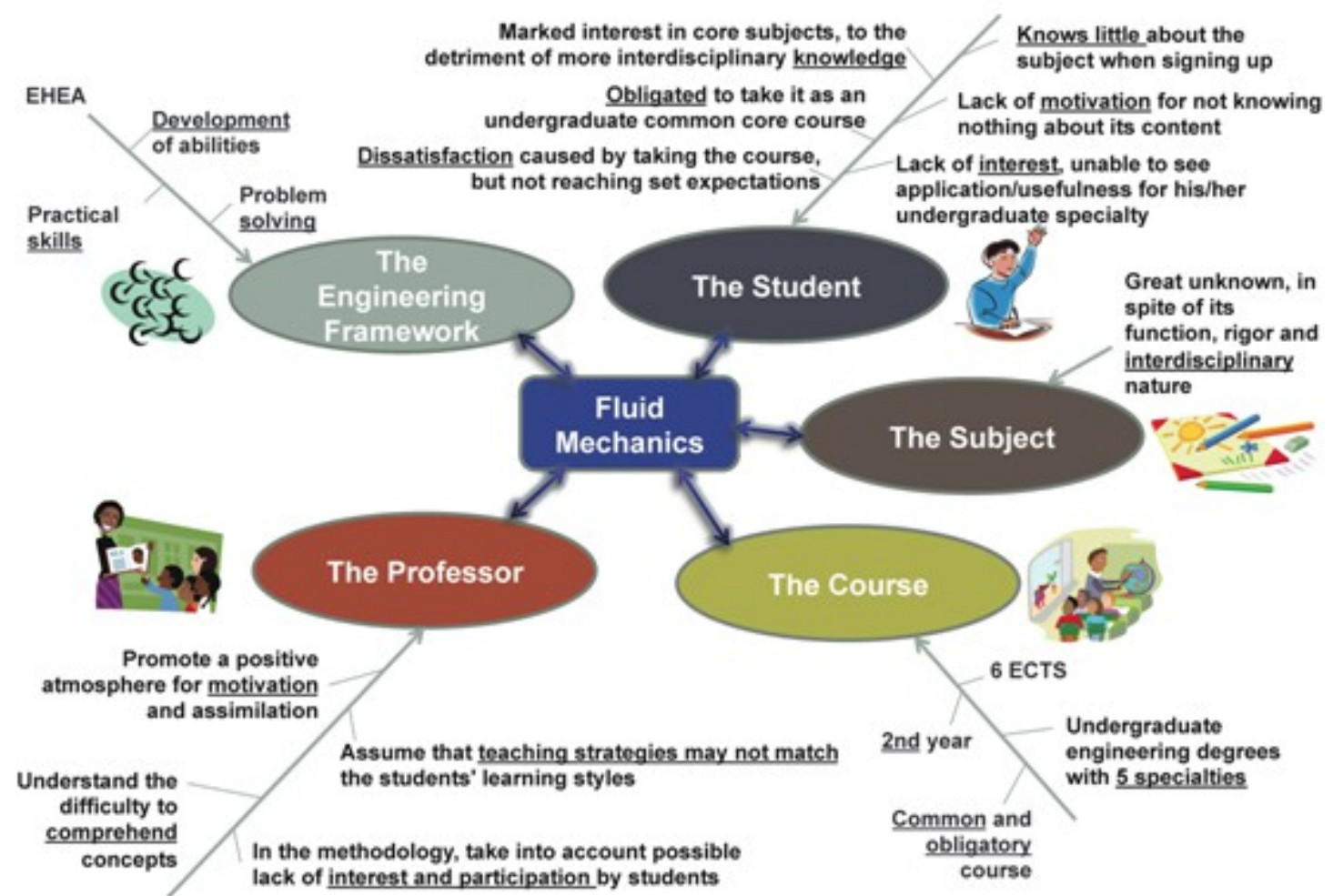

Figure 1. Mental map of the environment and context surrounding the Fluid Mechanics course 


\subsection{Planning and Teaching Materials}

Exhaustive planning is carried out, based on a syllabus of one-hour lessons, each with its corresponding subject matter. The lecture, exercise and laboratory hours are planned and made available on the Virtual Campus in such a way that students know exactly what is expected of them at all times. The Moodle ATENEA is the version of the Virtual Campus used at UPC.

All teaching materials for the course are available on the Virtual Campus from the start of the course. The notes for the lectures are structured exactly the same as the syllabus, with transparencies/notes for each one-hour lesson. The problem set for the course used for the exercise sessions is diverse and the problems are organized by topic, in such a way that they complement the lectures and serve as a tool for both classroom and group work and individual study at home. The practical laboratory activity instruction and report book contains the instructions on how to do each of the practical activities, additional information and questions. The reports contain spaces for the experimental data, the calculations and the results, as well as graph paper to show the corresponding graph, if appropriate.

The course rules and the teaching guide are available on the Virtual Campus from the start of the course. They contain information about evaluations and their respective weights, calendars, quizzes, exams, due dates, lab reports, rules for presentations and office numbers and office hours. They also contain a list of professors organized according to theoretical classroom lectures, problems and practical laboratory activities, which is very important, as it directs the students to the corresponding professor. When the time comes, grades and exam revisions are posted on the Virtual Campus.

\section{METHODOLOGY FOR LEARNING ACTIVITIES DESIGNED FOR FLUID MECHANICS}

The methodology used for the learning activities is based on tools for individual and group work in both the classroom and at home. The implementation of this methodology requires very close, coordinated collaboration among the 7 course professors. The faculty is coordinated by means of one main meeting at the end of the course, another before it and, during the course, personal meetings among the instructors and as a group on Moodle, where the explanations given in each lecture, problems, incidents, etc. are recorded in a particular section. This ensures that everything is documented and all class groups receive the same information, regardless of the professor teaching the course.

\subsection{Activity at the Beginning of the Course}

The self-assessment at the beginning of the course is administered individually as an online questionnaire that is made available to the students on the Virtual Campus during the first week of the course. It consists of approximately 15 multiple choice questions. It is to be completed individually, and three attempts are allowed during a one-week period. The advantage of this online questionnaire is that it allows students to evaluate their own knowledge about the subject matter and the course they are going to study. The intention is thus to let students know their starting point with regard to the course.

\subsection{Individual Activities}

These are the set of activities that are to be completed individually by the student, primarily as independent work done at home.

\subsubsection{Assignments}

Assignments, which are to be completed individually and in written form, are given on a regular basis throughout the course. Students are required to complete the assignments to ensure continuous learning throughout the duration of the course. The forums created on the Virtual Campus for each assignment foster communication among the students in order to answer any questions they might have and to solve problems. Professors participate in the forums, moderating them and providing information as necessary. Student participation is voluntary and is not evaluated. 


\subsubsection{Self-Assessment of Theoretical and Problem-Solving Lessons}

These are referred to in this way because they consist of an online questionnaire that is answered individually for the purposes of evaluating the student's own knowledge. The self-assessments are available to the students on the Virtual Campus. Two evaluations each term (for a total of four) are planned. They consist of approximately 25 multiple choice questions each, addressing theory and problems created on WIRIS. The data for the questions changes with each try, and thus so does the answers, which builds comprehension of the problem and the error. They are to be completed individually, and three attempts are allowed over a period of fifteen days. The big advantage of the online questionnaires is that they allow students to evaluate themselves and receive their score instantaneously, displaying the correct answers and marking the errors as soon as the questionnaire is completed.

\subsubsection{Self-Assessment of Practical Laboratory Exercises}

The self-assessment of practical laboratory exercises is administered individually as an online questionnaire that is made available to the students on the Virtual Campus. One is planned for the course, and it consists of 10 multiple choice questions on theory and/or problems created on WIRIS, related to the laboratory exercises. It will be completed individually and will allow a single attempt on the scheduled date and time. The selfassessment is intended to keep the students' attention focused on the value and importance of the laboratory activities, not just when they are engaged in them, rather on their direct relationship to the theoretical explanations and problems.

\subsubsection{Reading of a Scientific Journal Article}

The reading of a scientific journal article of interest related to Fluid Mechanics completes the individual work. According to Carson and Miller (Carson \& Miller, 2013), an activity of this nature during the early years of the undergraduate program considerably improves the students' research skills. Unfortunately, we are unable to dedicate as much time to its development and evaluation as would be advisable. This individual assignment includes a short critical analysis of the article. It is submitted by means of an online questionnaire, and a single attempt is allowed during the established period. A very positive assessment of this activity by the students can be inferred, as they express their opinion on learning about applications of Fluid Mechanics.

\subsection{Collaborative Activities}

Quizzes involve an element of camaraderie with a previously chosen classmate. The quiz is the same for all students and is answered in pairs in the classroom. Four quizzes are planned per course, two each term. Each consists of 8 multiple choice questions that address both theory and problems. The time allowed to take the quizzes is not sufficient for them to be answered individually, so cooperation with a partner is required.

\subsection{Team Activities}

The practical laboratory exercises build teamwork, as they are intended to be carried out in a group, promoting different roles among the students in a particular group and boosting cooperation. Cranston and Lock (2012), from the University of Bath, demonstrate the importance of practical group work in the specific case of Fluid Mechanics, in order to visually assimilate the concepts explained in the classroom.

The practical exercise team is made up of a group of 5 students. Each member of the team is assigned a data collection role in the laboratory so that the same person always reads the same instrument. This minimizes errors. The student/group must come to the laboratory having read the instructions and printed out the report to complete during the exercise with the experimental data, the calculations and the results.

The report for each practical exercise is completed immediately afterwards, at the computer station inside the laboratory itself. The professor in charge of the practical exercises is present at all times to guide the groups and answer any questions they might have. If everything is correct at the end of the practical exercise, the professor signs the report and the group has finished the practical exercise. Their final task is to upload the report onto the Virtual Campus.

This practical exercise methodology builds critical reasoning in the context of group work, fosters communication among the group members and different groups, and promotes discussion and reasoning, all

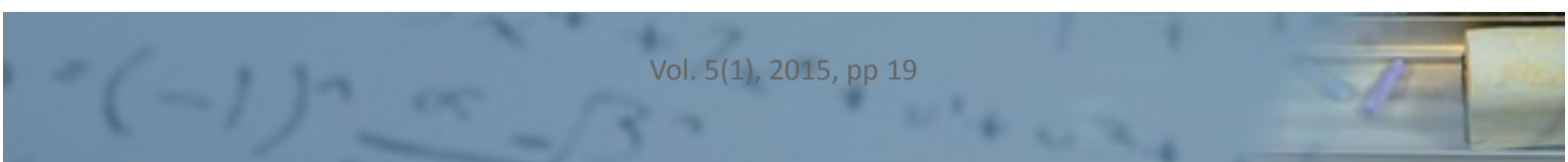


under the direct leadership and guidance of the professor. As a result, oral communication is particularly encouraged through questions and issues presented by group members and the professor, promoting both student-student and professor-student problem-solving discussions.

A book is available for the professors containing all the solutions for the practical exercise reports, along with data and results, so that the expected results are known for each practical exercise session, regardless of who the professor is. This also serves as a guide in the event of experimental errors and malfunctions. This aspect has proven especially relevant in improving the results obtained and the ratio between the performance in the exercise and the time spent.

\subsection{Classroom Activities}

The problem-solving sessions are conducted by the professor, and are dedicated to solving one or two problems on the blackboard with the entire class of students. These sessions guide the students through the problemsolving process, indicating the methodology and a six-point procedure to be followed:

- 1. Data/Order,

- 2. Hypothesis,

- 3. Sketch/Diagram,

- 4. Basic principles/concepts of Physics,

- 5. Explanation and

- 6. Solution, results and critical analysis.

\subsection{Assessment Activities (Exams)}

Partial and final exams are focused on demonstrating the student's analytical and problem-solving skills. Written exams show not only the student's knowledge of the subject matter learned, but also good written communication skills. Exams are corrected using a six-point rubric, where scores between 0 and 10 are assigned according to the procedure explained during the problem-solving sessions (see Table 1). The rubric is explained and provided to the students at the beginning of the course. For a detailed explanation of rubric assessment, consult Smit and Birri (2014) and the references for their work. The rubric has also been included, showing its indicators.

The rest of the activities are evaluated, each with their own weight. These include assignments, reading of articles, self-assessment on theory, self-assessment of practical exercises, quizzes and practical laboratory activities.

\begin{tabular}{|c|c|c|c|c|c|}
\hline Category & 10 & 7.5 & 5 & 2.5 & 0 \\
\hline $\begin{array}{l}\text { A. Sketches } \\
\text { and Drawings }\end{array}$ & $\begin{array}{l}\text { The sketches } \\
\text { and/or drawings } \\
\text { are clear and } \\
\text { help understand } \\
\text { the procedures }\end{array}$ & $\begin{array}{l}\text { The sketches } \\
\text { and/or drawings } \\
\text { are clear and } \\
\text { easy to } \\
\text { understand }\end{array}$ & $\begin{array}{l}\text { The sketches } \\
\text { and/or drawings } \\
\text { are a little } \\
\text { difficult to } \\
\text { understand }\end{array}$ & $\begin{array}{l}\text { The sketches } \\
\text { and/or drawings } \\
\text { are difficult to } \\
\text { understand }\end{array}$ & $\begin{array}{l}\text { No sketches or } \\
\text { drawings are } \\
\text { used }\end{array}$ \\
\hline $\begin{array}{l}\text { B. Neatness } \\
\text { and Order }\end{array}$ & $\begin{array}{l}\text { This work is } \\
\text { presented in a } \\
\text { way that is } \\
\text { orderly, clear and } \\
\text { organized so that } \\
\text { it is easy to read }\end{array}$ & $\begin{array}{l}\text { The work is } \\
\text { presented in a } \\
\text { way that is } \\
\text { orderly and } \\
\text { organized, so } \\
\text { that, generally } \\
\text { speaking, it is } \\
\text { easy to read }\end{array}$ & $\begin{array}{l}\text { This work is } \\
\text { presented in an } \\
\text { organized } \\
\text { manner, but it } \\
\text { may be difficult } \\
\text { to read }\end{array}$ & $\begin{array}{l}\text { The work } \\
\text { appears careless } \\
\text { and } \\
\text { disorganized. It is } \\
\text { difficult to } \\
\text { determine what } \\
\text { information is } \\
\text { related }\end{array}$ & $\begin{array}{l}\text { The work is } \\
\text { careless and } \\
\text { disorganized. It is } \\
\text { impossible to see } \\
\text { what information } \\
\text { is related }\end{array}$ \\
\hline
\end{tabular}

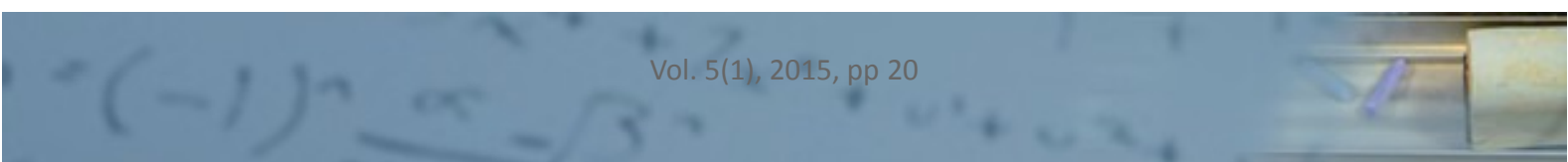




\begin{tabular}{|c|c|c|c|c|c|}
\hline Category & 10 & 7.5 & 5 & 2.5 & 0 \\
\hline C. Hypotheses & $\begin{array}{l}\text { Hypotheses are } \\
\text { clear, precise and } \\
\text { reasonable }\end{array}$ & $\begin{array}{l}\text { Some of the } \\
\text { hypotheses are } \\
\text { not clear or } \\
\text { precise or } \\
\text { reasonable }\end{array}$ & $\begin{array}{l}\text { Most of the } \\
\text { hypotheses make } \\
\text { no sense }\end{array}$ & $\begin{array}{l}\text { The most } \\
\text { important } \\
\text { working } \\
\text { hypotheses are } \\
\text { not suggested } \\
\text { and they are too } \\
\text { few in number }\end{array}$ & $\begin{array}{l}\text { No working } \\
\text { hypotheses are } \\
\text { written it down }\end{array}$ \\
\hline $\begin{array}{l}\text { D. Physical } \\
\text { Concepts }\end{array}$ & $\begin{array}{l}\text { The explanation } \\
\text { shows a } \\
\text { thorough } \\
\text { understanding of } \\
\text { the physical } \\
\text { concept used for } \\
\text { problem solving }\end{array}$ & $\begin{array}{l}\text { The explanation } \\
\text { shows } \\
\text { substantial } \\
\text { understanding of } \\
\text { the physical } \\
\text { concept used for } \\
\text { problem solving }\end{array}$ & $\begin{array}{l}\text { The explanation } \\
\text { shows some } \\
\text { degree of } \\
\text { understanding of } \\
\text { the physical } \\
\text { concept required } \\
\text { for problem } \\
\text { solving }\end{array}$ & $\begin{array}{l}\text { The explanation } \\
\text { shows a very } \\
\text { limited } \\
\text { understanding of } \\
\text { the underlying } \\
\text { concepts } \\
\text { required for } \\
\text { problem solving }\end{array}$ & $\begin{array}{l}\text { The explanation } \\
\text { shows that the } \\
\text { student has not } \\
\text { understood the } \\
\text { underlying } \\
\text { concepts } \\
\text { required for } \\
\text { problem solving } \\
\text { or has not } \\
\text { written it down }\end{array}$ \\
\hline E. Explanation & $\begin{array}{l}\text { The explanation } \\
\text { is clear and } \\
\text { detailed }\end{array}$ & $\begin{array}{l}\text { The explanation } \\
\text { is clear }\end{array}$ & $\begin{array}{l}\text { The explanation } \\
\text { is a little difficult } \\
\text { to understand, } \\
\text { but it includes } \\
\text { critical } \\
\text { components }\end{array}$ & $\begin{array}{l}\text { The explanation } \\
\text { is a little difficult } \\
\text { to understand } \\
\text { and it is missing } \\
\text { several } \\
\text { components }\end{array}$ & $\begin{array}{l}\text { No explanation } \\
\text { was included }\end{array}$ \\
\hline F. Results & $\begin{array}{l}\text { The results are } \\
\text { clear, correct and } \\
\text { use the proper } \\
\text { units }\end{array}$ & $\begin{array}{l}\text { The results are } \\
\text { not correct } \\
\text { however, they } \\
\text { are reasonable } \\
\text { and use the } \\
\text { proper units }\end{array}$ & $\begin{array}{l}\text { The results are } \\
\text { neither correct } \\
\text { nor reasonable, } \\
\text { however, they } \\
\text { use the proper } \\
\text { units }\end{array}$ & $\begin{array}{l}\text { The results are } \\
\text { either incorrect, } \\
\text { unreasonable or } \\
\text { do not use the } \\
\text { proper units }\end{array}$ & $\begin{array}{l}\text { The results are } \\
\text { neither correct } \\
\text { nor reasonable, } \\
\text { and they do not } \\
\text { use the proper } \\
\text { units }\end{array}$ \\
\hline
\end{tabular}

Table 1. Rubric and indicators for the assessment of partial and final exams in Fluid Mechanics

\section{RESULTS}

Tables 2 and 3, complemented by Figure 2, show the distribution of the 4 large classroom lecture groups made up by students from all 5 undergraduate specialties and one group of students who had not yet selected a specialty when registering for the course (designated by the acronym NS). In this analysis, it must once again be stressed that each classroom lecture group has a different professor. They show that specialty $M$ has the largest number of students (especially in group A), and more than either the EL or IE groups; however, the relevance of the NS group should be noted, particularly in the case of group A. 


\begin{tabular}{|c|c|c|c|c|c|}
\hline Specialty & A & B & C & D & Total \\
\hline $\begin{array}{c}\text { Electrical } \\
\text { Engineering (EL) }\end{array}$ & 17 & 15 & 12 & 11 & 55 \\
\hline $\begin{array}{c}\text { Industrial } \\
\text { Electronics and } \\
\text { Automation (IE) }\end{array}$ & 9 & 22 & 18 & 12 & 61 \\
\hline $\begin{array}{c}\text { Mechanical } \\
\text { Engineering (M) }\end{array}$ & 8 & 11 & 28 & 13 & 60 \\
\hline $\begin{array}{c}\text { Chemical } \\
\text { Engineering (CH) }\end{array}$ & 4 & 4 & 5 & 10 & 23 \\
\hline $\begin{array}{c}\text { Textile Technology } \\
\text { and Design (T) }\end{array}$ & 4 & 3 & 1 & 2 & 10 \\
\hline No Specialty (NS) & 8 & 11 & 5 & 7 & 31 \\
\hline Total & 50 & 66 & 69 & 55 & 240 \\
\hline
\end{tabular}

Table 2. Distribution of students by specialties and groups. Academic year 2012/2013

\begin{tabular}{|c|c|c|c|c|c|}
\hline Specialty & A & B & C & D & Total \\
\hline $\begin{array}{c}\text { Electrical } \\
\text { Engineering (EL) }\end{array}$ & 5 & 9 & 5 & 6 & 25 \\
\hline $\begin{array}{c}\text { Industrial } \\
\text { Electronics and } \\
\text { Automation (IE) }\end{array}$ & 8 & 12 & 14 & 9 & 43 \\
\hline $\begin{array}{c}\text { Mechanical } \\
\text { Engineering (M) }\end{array}$ & 10 & 18 & 23 & 11 & 62 \\
\hline $\begin{array}{c}\text { Chemical } \\
\text { Engineering (CH) }\end{array}$ & 1 & 9 & 5 & 4 & 19 \\
\hline $\begin{array}{c}\text { Textile Technology } \\
\text { and Design (T) }\end{array}$ & 2 & 0 & 11 & 4 & 17 \\
\hline No Specialty (NS) & 29 & 12 & 9 & 15 & 65 \\
\hline Total & 55 & 60 & 67 & 49 & 231 \\
\hline
\end{tabular}

Table 3. Distribution of students by specialties and groups. Academic year 2013/2014

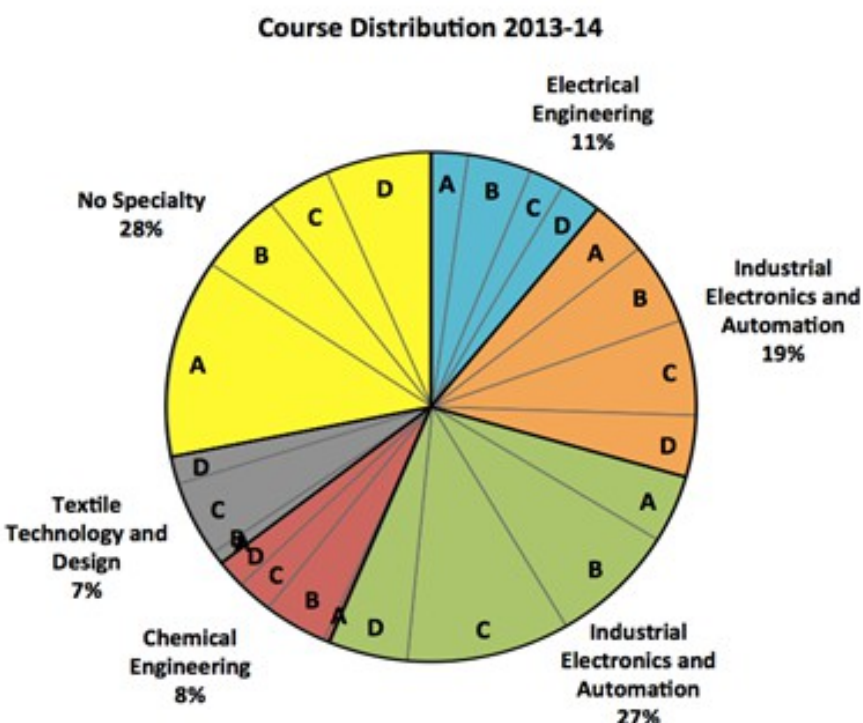

Figure 2. Percentages of the distribution of groups by specialties. Academic year 2013/2014 
Tables 4 and 5 show the percentages of students who have passed and failed the course (percentages of failing students are indicated in parentheses), for two consecutive academic years. In both cases, the percentages shown correspond to the groups as compared to the course total. For the two years analyzed, better results are observed for the specialties M, IE and EL than for the remaining specialties, in terms of both the number of passing students and the low number of students who failed the course.

This trend can also be extrapolated to the analysis of the classroom lecture groups. Those groups made up predominantly by students with specialties that might be considered the most closely related to the course subject matter show the best results, as in the case of $B$ and $C$; conversely, the trends are diffuse for those groups with a homogeneity of specialties. In the case of group A, responses from NS students predominate, and in the case of group D, the response is more equal, as shown in Figure 2.

These observations coincide with the opinions of the professors of the groups. Tables 4 and 5 show a predominance of the specialties $\mathrm{M}$, EL and IE over the specialties $\mathrm{T}$ and $\mathrm{CH}$. As an example of the results observed, it can be seen that in the two periods analyzed, M and IE have indicators closely correlated with the number of students per specialty in each group, when comparing Tables 2 and 4, and Tables 3 and 5 . This establishes a motivation and performance factor that is noticeably different among the different groups.

\begin{tabular}{|c|c|c|c|c|c|}
\hline Specialty & $\boldsymbol{A}$ & $\boldsymbol{B}$ & $\boldsymbol{C}$ & $\boldsymbol{D}$ & Total \\
\hline $\begin{array}{c}\text { Electrical Engineering } \\
(\text { EL) }\end{array}$ & $22 \%(12 \%)$ & $17 \%(6 \%)$ & $16 \%(1 \%)$ & $16 \%(4 \%)$ & $18 \%(5 \%)$ \\
\hline $\begin{array}{c}\text { Industrial Electronics } \\
\text { and Automation (IE) }\end{array}$ & $14 \%(4 \%)$ & $32 \%(2 \%)$ & $26 \%(0 \%)$ & $22 \%(0 \%)$ & $24 \%(1 \%)$ \\
\hline $\begin{array}{c}\text { Mechanical } \\
\text { Engineering (M) }\end{array}$ & $16 \%(0 \%)$ & $17 \%(0 \%)$ & $38 \%(3 \%)$ & $24 \%(0 \%)$ & $24 \%(1 \%)$ \\
\hline $\begin{array}{c}\text { Chemical Engineering } \\
(C H)\end{array}$ & $6 \%(2 \%)$ & $6 \%(0 \%)$ & $7 \%(0 \%)$ & $18 \%(0 \%)$ & $9 \%(0 \%)$ \\
\hline $\begin{array}{c}\text { Textile Technology and } \\
\text { Design (T) }\end{array}$ & $6 \%(2 \%)$ & $5 \%(0 \%)$ & $0 \%(1 \%)$ & $4 \%(0 \%)$ & $3 \%(1 \%)$ \\
\hline No Specialty (NS) & $16 \%(0 \%)$ & $17 \%(0 \%)$ & $7 \%(0 \%)$ & $11 \%(1 \%)$ & $13 \%(1 \%)$ \\
\hline Total & $80 \%(20 \%)$ & $92 \%(8 \%)$ & $94 \%(6 \%)$ & $95 \%(5 \%)$ & $91 \%(9 \%)$ \\
\hline
\end{tabular}

Table 4. Academic year 2012/13 - Percentages of the distribution of students passing the course (the percentage of students failing the course is indicated in parentheses), by group and specialty

\begin{tabular}{|c|c|c|c|c|c|}
\hline Specialty & $\boldsymbol{A}$ & $\boldsymbol{B}$ & $\boldsymbol{C}$ & $\boldsymbol{D}$ & Total \\
\hline $\begin{array}{c}\text { Electrical Engineering } \\
(\text { EL) }\end{array}$ & $9 \%(3 \%)$ & $12 \%(3 \%)$ & $6 \%(1 \%)$ & $14 \%(1 \%)$ & $11 \%(1 \%)$ \\
\hline $\begin{array}{c}\text { Industrial Electronics } \\
\text { and Automation (IE) }\end{array}$ & $14 \%(2 \%)$ & $17 \%(3 \%)$ & $22 \%(2 \%)$ & $19 \%(2 \%)$ & $18 \%(2 \%)$ \\
\hline $\begin{array}{c}\text { Mechanical } \\
\text { Engineering (M) }\end{array}$ & $17 \%(2 \%)$ & $28 \%(2 \%)$ & $31 \%(2 \%)$ & $24 \%(1 \%)$ & $26 \%(2 \%)$ \\
\hline $\begin{array}{c}\text { Chemical Engineering } \\
(\text { CH) }\end{array}$ & $1 \%(2 \%)$ & $15 \%(0 \%)$ & $6 \%(1 \%)$ & $14 \%(1 \%)$ & $7 \%(1 \%)$ \\
\hline $\begin{array}{c}\text { Textile Technology and } \\
\text { Design (T) }\end{array}$ & $4 \%(1 \%)$ & $0 \%(2 \%)$ & $15 \%(1 \%)$ & $9 \%(1 \%)$ & $7 \%(1 \%)$ \\
\hline No Specialty (NS) & $39 \%(6 \%)$ & $18 \%(0 \%)$ & $7 \%(6 \%)$ & $12 \%(2 \%)$ & $19 \%(5 \%)$ \\
\hline Total & $84 \%(16 \%)$ & $90 \%(10 \%)$ & $87 \%(13 \%)$ & $92 \%(8 \%)$ & $88 \%(12 \%)$ \\
\hline
\end{tabular}

Table 5. Academic year 2013/14 - Percentages of the distribution of students passing the course (the percentage of students failing the course is indicated in parentheses), by group and specialty

The conclusions of the present analysis are further supported by a comparison of the distribution of grades by specialty and group, since the exams used to evaluate the students are the same for all four classroom lecture groups, regardless of the professor. Tables $6,7,8$ and 9 show the figures for the classification of those students who earned high grades, $>=8 / 10$, and those students who earned average passing grades of between 5 and 8 .

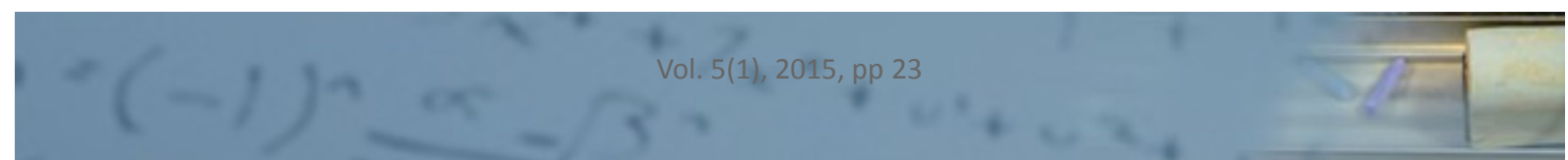


At first glance, the figures revel that those groups with the largest number of students from specialties the most closely related to the course subject matter are those demonstrating the best performance.

\begin{tabular}{|c|c|c|c|c|c|}
\hline Specialty & $\boldsymbol{A}$ & $\boldsymbol{B}$ & $\boldsymbol{C}$ & $\boldsymbol{D}$ & Total \\
\hline $\begin{array}{c}\text { Electrical Engineering } \\
(\text { EL) }\end{array}$ & $0 \%(0 \%)$ & $0 \%(0 \%)$ & $0 \%(0 \%)$ & $0 \%(0 \%)$ & $0 \%$ \\
\hline $\begin{array}{c}\text { Industrial Electronics } \\
\text { and Automation (IE) }\end{array}$ & $4 \%(1 \%)$ & $2 \%(0 \%)$ & $6 \%(2 \%)$ & $2 \%(0 \%)$ & $3 \%$ \\
\hline $\begin{array}{c}\text { Mechanical } \\
\text { Engineering (M) }\end{array}$ & $4 \%(1 \%)$ & $3 \%(1 \%)$ & $4 \%(1 \%)$ & $4 \%(1 \%)$ & $4 \%$ \\
\hline $\begin{array}{c}\text { Chemical Engineering } \\
(C H)\end{array}$ & $2 \%(1 \%)$ & $0 \%(0 \%)$ & $4 \%(1 \%)$ & $2 \%(1 \%)$ & $3 \%$ \\
\hline $\begin{array}{c}\text { Textile Technology } \\
\text { and Design (T) }\end{array}$ & $0 \%(0 \%)$ & $0 \%(0 \%)$ & $0 \%(0 \%)$ & $2 \%(0 \%)$ & $0 \%$ \\
\hline No Specialty (NS) & $0 \%(0 \%)$ & $0 \%(0 \%)$ & $0 \%(0 \%)$ & $0 \%(0 \%)$ & $0 \%$ \\
\hline Total & $10 \%(3 \%)$ & $5 \%(1 \%)$ & $14 \%(4 \%)$ & $10 \%(2 \%)$ & $10 \%$ \\
\hline
\end{tabular}

Table 6. Academic year 2012/13 - Percentages of grades equal to or better than 8/10, by group and specialty (the percentage of the total is indicated in parentheses)

\begin{tabular}{|c|c|c|c|c|c|}
\hline Specialty & $\boldsymbol{A}$ & $\boldsymbol{B}$ & $\boldsymbol{C}$ & $\boldsymbol{D}$ & Total \\
\hline $\begin{array}{c}\text { Electrical Engineering } \\
(\text { EL) }\end{array}$ & $0 \%(0 \%)$ & $0 \%(0 \%)$ & $0 \%(0 \%)$ & $0 \%(0 \%)$ & $0 \%$ \\
\hline $\begin{array}{c}\text { Industrial Electronics } \\
\text { and Automation (IE) }\end{array}$ & $0 \%(0 \%)$ & $0 \%(0 \%)$ & $1 \%(0 \%)$ & $4 \%(1 \%)$ & $1 \%$ \\
\hline $\begin{array}{c}\text { Mechanical } \\
\text { Engineering (M) }\end{array}$ & $0 \%(0 \%)$ & $12 \%(3 \%)$ & $4 \%(1 \%)$ & $4 \%(1 \%)$ & $5 \%$ \\
\hline $\begin{array}{c}\text { Chemical Engineering } \\
(C H)\end{array}$ & $0 \%(0 \%)$ & $5 \%(1 \%)$ & $1 \%(1 \%)$ & $0 \%(0 \%)$ & $2 \%$ \\
\hline $\begin{array}{c}\text { Textile Technology and } \\
\text { Design (T) }\end{array}$ & $0 \%(0 \%)$ & $0 \%(0 \%)$ & $0 \%(0 \%)$ & $4 \%(1 \%)$ & $1 \%$ \\
\hline No Specialty (NS) & $2 \%(0 \%)$ & $0 \%(0 \%)$ & $1 \%(1 \%)$ & $0 \%(0 \%)$ & $1 \%$ \\
\hline Total & $2 \%(0 \%)$ & $17 \%(4 \%)$ & $7 \%(3 \%)$ & $12 \%(3 \%)$ & $10 \%$ \\
\hline
\end{tabular}

Table 7. Academic year 2013/14 - Percentages of grades equal to or better than 8/10, by group and specialty (the percentage of the total is indicated in parentheses)

\begin{tabular}{|c|c|c|c|c|c|}
\hline Specialty & $\boldsymbol{A}$ & $\boldsymbol{B}$ & $\boldsymbol{C}$ & $\boldsymbol{D}$ & Total \\
\hline $\begin{array}{c}\text { Electrical Engineering } \\
(\text { EL) }\end{array}$ & $22 \%(5 \%)$ & $17 \%(4 \%)$ & $16 \%(5 \%)$ & $16 \%(4 \%)$ & $18 \%$ \\
\hline $\begin{array}{c}\text { Industrial Electronics } \\
\text { and Automation (IE) }\end{array}$ & $10 \%(2 \%)$ & $30 \%(8 \%)$ & $20 \%(6 \%)$ & $20 \%(5 \%)$ & $21 \%$ \\
\hline $\begin{array}{c}\text { Mechanical } \\
\text { Engineering (M) }\end{array}$ & $12 \%(3 \%)$ & $14 \%(3 \%)$ & $33 \%(9 \%)$ & $20 \%(5 \%)$ & $20 \%$ \\
\hline $\begin{array}{c}\text { Chemical Engineering } \\
(\text { CH) }\end{array}$ & $4 \%(1 \%)$ & $6 \%(2 \%)$ & $3 \%(1 \%)$ & $16 \%(4 \%)$ & $7 \%$ \\
\hline $\begin{array}{c}\text { Textile Technology } \\
\text { and Design (T) }\end{array}$ & $6 \%(1 \%)$ & $5 \%(1 \%)$ & $0 \%(0 \%)$ & $2 \%(1 \%)$ & $3 \%$ \\
\hline No Specialty (NS) & $16 \%(3 \%)$ & $17 \%(5 \%)$ & $7 \%(2 \%)$ & $11 \%(2 \%)$ & $12 \%$ \\
\hline Total & $70 \%(15 \%)$ & $88 \%(23 \%)$ & $80 \%(23 \%)$ & $85 \%(20 \%)$ & $81 \%$ \\
\hline
\end{tabular}

Table 8. Academic year 2012/13 - Percentages of average passing grades ( $>=5 / 10$ and $<8 / 10)$, by group and specialty (the percentage of the total is indicated in parentheses) 


\begin{tabular}{|c|c|c|c|c|c|}
\hline Specialty & $\boldsymbol{A}$ & $\boldsymbol{B}$ & $\boldsymbol{C}$ & $\boldsymbol{D}$ & Total \\
\hline $\begin{array}{c}\text { Electrical Engineering } \\
(\text { EL) }\end{array}$ & $9 \%(2 \%)$ & $12 \%(3 \%)$ & $6 \%(2 \%)$ & $12 \%(3 \%)$ & $10 \%$ \\
\hline $\begin{array}{c}\text { Industrial Electronics } \\
\text { and Automation (IE) }\end{array}$ & $13 \%(3 \%)$ & $17 \%(4 \%)$ & $19 \%(6 \%)$ & $12 \%(3 \%)$ & $16 \%$ \\
\hline $\begin{array}{c}\text { Mechanical } \\
\text { Engineering (M) }\end{array}$ & $16 \%(4 \%)$ & $17 \%(4 \%)$ & $27 \%(7 \%)$ & $18 \%(4 \%)$ & $19 \%$ \\
\hline $\begin{array}{c}\text { Chemical Engineering } \\
(C H)\end{array}$ & $0 \%(0 \%)$ & $10 \%(3 \%)$ & $4 \%(1 \%)$ & $8 \%(2 \%)$ & $6 \%$ \\
\hline $\begin{array}{c}\text { Textile Technology and } \\
\text { Design (T) }\end{array}$ & $42 \%(9 \%)$ & $18 \%(5 \%)$ & $7 \%(2 \%)$ & $20 \%(4 \%)$ & $20 \%$ \\
\hline No Specialty (NS) & $2 \%(1 \%)$ & $0 \%(0 \%)$ & $13 \%(4 \%)$ & $8 \%(2 \%)$ & $7 \%$ \\
\hline Total & $82 \%(19 \%)$ & $73 \%(19 \%)$ & $78 \%(22 \%)$ & $80 \%(18 \%)$ & $78 \%$ \\
\hline
\end{tabular}

Table 9. Academic year 2013/14 - Percentages of average passing grades (>=5/10 and <8/10), by group and specialty (the percentage of the total is indicated in parentheses)

The statistics in Tables 6 and 7 indicate that the largest proportion of students with grades equal to or better than $8 / 10$ are from the specialty $M$, followed by EL and IE, as shown graphically in Figure 3 . In the case of the academic year $2013 / 14,40 \%$ of all students with a grade equal to or better than $8 / 10$ had the specialty M. This trend continued and even increased during the following year, to $50 \%$. When we analyze the interval of average grades between 5 and 8, the groups are shown to become more homogenized in terms of specialties (see Tables 8 and 9). Figure 4, however, highlights groups that might be expected to have less interest in the course content, as in the case of groups $\mathrm{T}$ and $\mathrm{CH}$. The course assessment system is responsible for this homogenization.

The observations lead us to conclude that those classroom lecture groups that include students with specialties that are closely oriented towards mechanical-electrical principles are more aware of the importance of the course contents. On the contrary, the group of students who had specified no specialty showed heterogeneous performance levels that were difficult to predict, and they tended not to attain the final course objectives. It might be concluded that students with specialties such as $\mathrm{CH}$ and $\mathrm{T}$ are misinformed and believe that the objectives and applications of Fluid Mechanics are clearly unrelated to their specialty.

\section{Passing/Failing Students 2013-14}

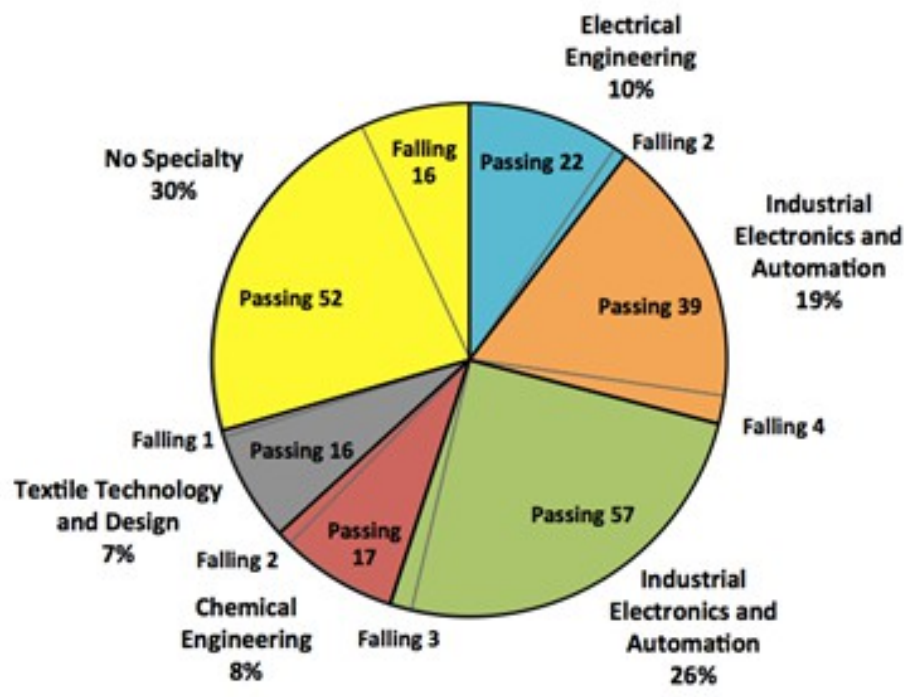

Figure 3. Percentage and number of passing/failing students by specialty. Academic year 2013/2014 


\section{Passing/Falling Students 2013-14}

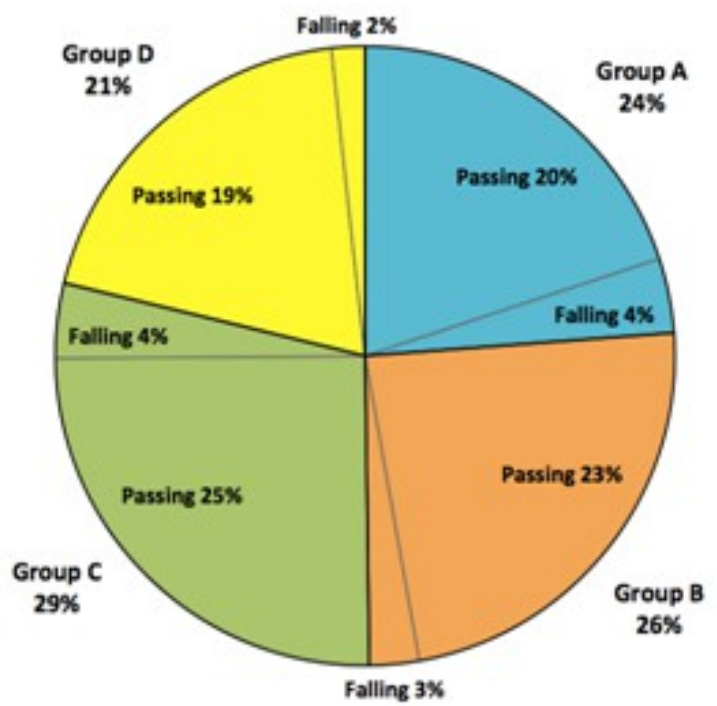

Figure 4. Percentage and number of passing/failing students by group. Academic year 2013/2014

Another complementary analysis can be performed using the survey administered by UPC. This includes 9 questions, of which 5 have been highlighted in relation to this work: interest, learning, progress, Virtual Campus and satisfaction. Figure 5 shows a course score for each section greater than 3 , with a slight, yet hopeful positive evolution, especially with regard to the use of the Virtual Campus, which is attributed to the online questionnaires.

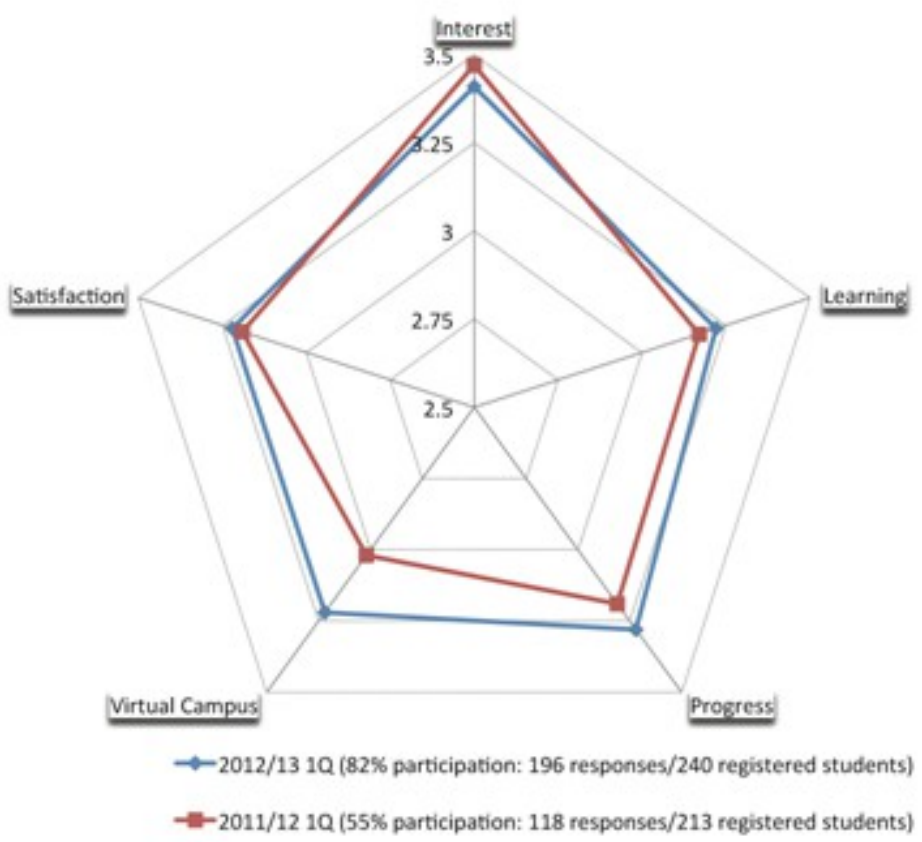

Figure 5. Evolution of the official course survey administered by the University (evaluation scale: 1-Strongly disagree to 5-Strongly agree) 


\section{CONCLUSIONS}

The study allows us to draw the following relevant conclusions:

- The figures reveal that those groups with the largest number of students with specialties related to the course subject matter show the best performance, fostering a much more motivating and highperforming work environment, with fewer distractions and interruptions, which enhances learning.

- The distributions of the specialties in the classroom lecture groups are not homogeneous and definitely mark the trend of the group with regard to its evolution throughout the course, which indicates that efforts should be made to improve this distribution.

- The number of students without a specialty increased from year to year, and their heterogeneous distribution makes it more difficult to concentrate efforts aimed at motivating them. In terms of the total percentage, this increase was reflected in the evolution of the group with the largest percentage of failing grades, which was also the group with the largest percentage of students without a specialty.

- The cut-off grade for undergraduate studies at EET is the same for each specialty, and thus it was automatically eliminated as an indicator in this study.

Nonetheless, the main conclusion of this work is the need for the study itself, to identify more precise strategies focused on the teaching of Fluid Mechanics, in order to better motivate those students who, due to a lack of knowledge or motivation, fail to appreciate the importance of the subject in the overall context of their curriculum. These strategies should take into account that:

- Activities in which students actively participate, where they are not merely passive recipients of information, are those that they like the best.

- Students value activities in which they participate as a team.

- It is important to present practical cases that have some connection to the specialties of the different groups of students.

- The course contents must be broken down to a greater degree in accordance with student expectations.

- Efforts must be intensified to provide guidance and assistance to those students who are the most "lost".

- $\quad$ One trend that has been observed is the proportion of all students without a declared specialty during the last period analyzed. This may be attributable to certain degree of uncertainty with regard to their professional future.

- If the students were divided into classroom lecture groups according to their specialties, differential instruction could be provided to each group, making the course more attractive and useful for each profile.

In terms of future work, it is difficult to predict the changes that would be the most successful and provocative, where students with specialties closely tied to Fluid Mechanics would show the greatest interest and obtain the most satisfactory results. The challenge lies in posing differential instruction for students in the groups $\mathrm{T}, \mathrm{CH}$ and NS.

Promising proposals for change could be the teaching of the basic principles that dominate Fluid Mechanics by presenting real, practical cases that have to do with each of the specialties, according to which the syllabus would not be organized in any theoretical order, rather by application. Students would be better motivated by relating Fluid Mechanics to the engineering degree they wish to study.

However, it should not be overlooked that the above also poses a risk that must be carefully assessed: learning and managing the basic principles and fundamentals that govern Fluid Mechanics through the presentation of real cases could prove to be overwhelming. Instead of making the subject more accessible to the students and motivating them, it might have the opposite effect. 


\section{ACKNOWLEDGMENTS}

The authors of this work wish to thank the students in the undergraduate program for their collaboration on the activities and questionnaires they were asked to do for this study. There is no question that their opinions and comments have helped us to improve our teaching activity.

\section{REFERENCES}

Absi, R., Nalpas, C., Dufour, F., Huet, D., Bennacer, R., \& Absi, T. (2011). Teaching Fluid Mechanics for Undergraduate Students in Applied Industrial Biology: From Theory to Atypical Experiments, 27(3), 550-558. http://arxiv.org/pdf/1106.0656.pdf

Barrio, R., Blanco, E., Martinez, J., \& Galdo, M. (2010). El aprendizaje orientado a proyectos en Mecánica de Fluidos a través de la experimentación con cohetes de agua, RED. Docencia Universitaria en la Sociedad del Conocimiento, 2, 1-12.

Campus Virtual ATENEA, Universitat Politècnica de Catalunya.

Carson, S., \& Miller, S.E. (2013). Introducing primary scientific literature to first-year undergraduate researchers. CURQ on the Web, 34, 17-22.

Cranston, G., \& Lock, G. (2012). Techniques to encourage interactive student learning in a laboratory setting. Engineering Education, 7(1), 2-10. http://dx.doi.org/10.11120/ened.2012.07010002

Felder, R.M. (2014). Why are you teaching that?. Chem. Eng. Ed., 48(3), 131-132.

Gad-el-Hak, M. (1998). Fluid Mechanics from the Beginning to the Third Millennium. International Journal of Engineering Education, 14(3), 177-185.

Gynnild, V., Myrhaug, D., \& Pettersen, B. (2007). Introducing Innovative Approaches to Learning in Fluid Mechanics: a Case Study. European Journal of Engineering Education, 32(5), 503-516. http://dx.doi.org/10.1080/03043790701433137

Kolb, D.A. (1984) Experiential Learning. Experience as the source of learning and development. Englewood Cliffs, New Jersey: Prentice Hall PTR.

Kumar, V., Ramana, C., Afrin, S., Ortega, J., Agarwal, N., \& Udoewa, V. (2013, July). Touchpad in Education: Dynamic Learning Framework Assessment and Content Development for the Undergraduate Fluid Mechanics. In ASME 2013 Fluids Engineering Division Summer Meeting (pp. V01AT01A004-V01AT01A004). American Society of Mechanical Engineers.

Mills, J., \& Treagust, D.F. (2003). Engineering Education - Is Problem-based or Project-based Learning the Answer?. Australasian J. of Engng. Educ., 1-16. Retrieved from:

http://www.aaee.com.au/journal/2003/mills treagust03.pdf

Smit, R., \& Birri, T. (2014). Assuring the quality of standards-oriented classroom assessment with rubrics for complex competencies. Studies in Educational Evaluation, Available online 4 March 2014, ISSN 0191-491X, http://dx.doi.org/10.1016/j.stueduc.2014.02.002.

WIRIS. Retrieved from: http://www.wiris.com/

Citation: Gamez-Montero, P.J., Raush, G., Domenech, L., Castilla, R., García-Vílchez, M., Moreno, H., Carbó, A. (2015). Methodology for developing teaching activities and materials for use in fluid mechanics courses in undergraduate engineering programs. Journal of Technology and Science Education (JOTSE), 5(1), 15-30. http://dx.doi.org/10.3926/jotse.135

On-line ISSN: 2013-6374 - Print ISSN: 2014-5349 - DL: B-2000-2012 


\section{AUTHOR BIOGRAPHY}

\section{Pedro Javier Gamez-Montero}

P. Javier Gamez-Montero obtained his MSc (1999) and, with a 4 years's grant, his PhD (2004) in Mechanical Engineering both at the Universitat Politècnica de Catalunya (UPC). From 2004 to 2008 he was an Adjunct Lecturer, an Assistant Lecturer and a Temporary Lecturer. Since 2009 he has been an Associate Professor at the above-mentioned university. He teaches in the Bachelor's Degree in Industrial Technology Engineering, in the Aerospace Technology Engineering and in the Aerospace Vehicle Engineering, being coordinator of several subjects in those Degrees.

With regard to his research activities, his main research field is fluid power technology by using numerical, dynamical and experimental techniques, such as Bond Graph, CFD and TRPIV, being lead/coordinator researcher of national competitive research projects, researcher in international projects in the LABSON research group, and author of more than fifteen papers. Dr. Gamez-Montero's research interest includes pedagogic innovation in higher education and he has participated in seminars and projects related to innovative teaching, publishing the results in an international conference.

\section{Gustavo Raush}

Gustavo Raush obtained his degree in 1989 on electrical/electronic engineering with honor to "Best Promotion Grade". During 1984 to 1995 he hold several academic positions. In 1995 he got a tenure-track associated professor position of Physics Department, at the ICCyC Institute on Universidad Nacional del Nordeste, Argentina. In 2008, he reached the PhD in Thermal Engineering at the Universitat Politècnica de Catalunya (BarcelonaTECH - UPC). In September 2009, he became tenure-track Lecturer professor at the Department of Fluid Mechanics at UPC. He focused his research activities mainly on experimental fluid dynamics, flow visualization, measurement techniques and aerodynamic tests. He is also interested in teaching practices to develop positive and motivating learning environments, therefore his lectures are continuously reinforced with his research experience.

\section{Lluís M. Domènech Rubio}

Graduate in Applied Geology in the University of Barcelona and Master in Environmental Engineering in the Universitat Politècnica de Catalunya (UPC). His current position is Associate Professor in the Department of Fluid Mechanics. He has been researching in hydrodynamic transport and dispersion in porous media. His current interest field is Computational Environmental Contaminant Transport Modeling in porous and fractured aquifers.

\section{Robert Castilla López}

Ph.D. in Applied Physics in the Universitat Politècnica de Catalunya (UPC). His current position is Associate Professor in the Department of Fluid Mechanics. He has been researching in Turbulence and in Particle Image Velocimetry applied to internal flows. His current interest field is Computational Fluid Dynamics for multiphase flows both in macroscale and microscale, and internal complex flows in Fluid Power components.

\section{Mercedes García-Vílchez}

M. García-Vílchez is a member of the Fluid Mechanics Department at the Universitat Politècnica de Catalunya (UPC) and she is also part of the research center LABSON - UPC (Laboratorio de Sistemas Oleohidráulicos y Neumáticos). She earned a degree in Mechanical Engineering in 2010, and a PhD from UPC in 2014 (Mechanical Engineering, Fluids and Aeronautics programme). With a strong teaching and research vocation, she works as an associate professor in UPC since 2010. Her research has focused on the study of fluid dynamics of hydraulic systems, and she has worked mainly in Computational Fluid Dynamics and Particle Image Velocimetry methodologies.

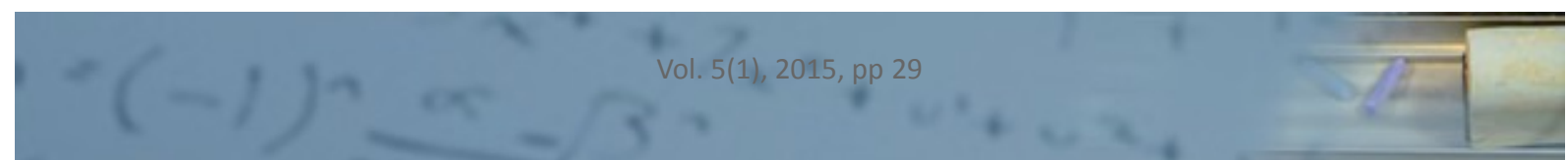




\section{Hipòlit Moreno Llagostera}

Hipòlit Moreno Llagostera obtained his degree in Mechanical Engineering from the Universitat Politècnica de Catalunya (UPC), and now he is Associate Professor in Fluid Mechanics at the same University. MBA in General Management Program from ESADE Business School. He has published several papers at specialized journals and has presented contributions in several International conferences.

\section{Albert Carbó Bech}

Albert Carbó obtained his degree in Industrial Mechanical Engineering from the Universitat Politècnica de Catalunya (Barcelona, Spain), and now is Associate Professor in Fluids Mechanics at the same university. He is writing his thesis focused on Fluid Pipelines leak detection using transient-based methods. He is author of several patents.

Published by OmniaScience (www.omniascience.com)

$$
\text { 0 }
$$

Journal of Technology and Science Education, 2015 (www.jotse.org)

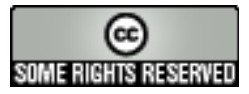

Article's contents are provided on a Attribution-Non Commercial 3.0 Creative commons license. Readers are

allowed to copy, distribute and communicate article's contents, provided the author's and JOTSE journal's names are included. It must not be used for commercial purposes. To see the complete licence contents, please visit http://creativecommons.org/licenses/by-nc/3.0/es/ 